Article

\title{
Empowering Sustainable Consumer Behavior in the EU by Consolidating the Roles of Waste Recycling and Energy Productivity
}

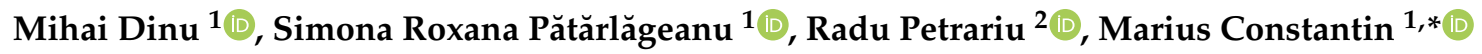 \\ and Ana-Mădălina Potcovaru ${ }^{3}$ (D) \\ 1 Faculty of Agri-Food and Environmental Economics, The Bucharest University of Economic Studies, \\ 010374 Bucharest, Romania; mihai.dinu@eam.ase.ro (M.D.); rpatarlageanu@eam.ase.ro (S.R.P.) \\ 2 Faculty of International Business and Economics, The Bucharest University of Economic Studies, \\ 010374 Bucharest, Romania; radu.petrariu@rei.ase.ro \\ 3 Faculty of Administration and Public Management, The Bucharest University of Economic Studies, \\ 010374 Bucharest, Romania; ana.potcovaru@amp.ase.ro \\ * Correspondence: constantinmarius15@stud.ase.ro
}

Received: 25 October 2020; Accepted: 21 November 2020; Published: 24 November 2020

\begin{abstract}
The growth in population and economic activities has direct implications on the deterioration of the natural capital, especially when referring to the increase in greenhouse gas emissions. However, improvement is possible by empowering sustainable consumption and production patterns. Through the 2030 Agenda for Sustainable Development, the United Nations call for a mix of economic development, environmental sustainability, and social inclusion. The agenda also provides the instruments needed to track progress, as each Sustainable Development Goal has a set of indicators meant to assess various dimensions of sustainability. Energy productivity is only one of many, but still special because it reflects sustainable consumption behaviors and production patterns. The 2030 Climate Target Plan elaborated by the European Commission consolidates and brings its contribution to the aims of the 2030 Agenda for Sustainable Development by adding weight to the importance of the greenhouse gas emissions target. The objective of this research was to study the relationship between energy productivity, greenhouse gas emissions, biowaste recycling and nominal GDP in the EU in order to highlight the key of a smooth transition towards sustainable consumption behaviors and production patterns. The results show that recycling, greening the economy and energy productivity are the vectors of this transition.
\end{abstract}

Keywords: sustainable consumption habits; sustainable development goals; European Union; climate target plan; green economy

\section{Introduction}

The future of consumption can no longer be approached without considering sustainability. Consumption behaviors have many implications on achieving the goals and targets of sustainable development. In the EU, sustainable development is the main orientation of development. Decision-makers prioritize the sustainability factor when designing policies, as this contributes to the generation of better conditions for the EU citizens.

The economic, social, and environmental dimensions need to be approached simultaneously when designing policies, because they all influence the future of sustainable development. Decision-makers all over the world should promote renewable energy sources and energy efficiency as means for complying with the aims and goals of sustainable development. 
Sustainable development is a concept defined by the United Nations in the document "Our Common Future" as "the development that meets the needs of the present without compromising the ability of future generations to meet their own needs" [1]. The 2030 Agenda for Sustainable Development is an action plan adopted by the General Assembly of the United Nations in 2015, whose aim is to end poverty and hunger, to protect the planet from degradation by fighting against it with measures that encourage sustainable consumption and production and that call for urgent actions on climate change, so that the environment can support the needs of the present and future generations [2]. The 2030 Agenda for Sustainable Development contains 17 Sustainable Development Goals (SDGs), which are used to provide indications and to measure the progress made towards the main objective of sustainable development [3]. These goals represent a shared expression of the need for a global balanced social, economic and ecological development [4]. As for synergy, the SDGs' logic implies the existence of mutual dependence between the SDGs [5].

Waste generation and recycling behaviors have an impact on environmental sustainability: they can either deepen the classic linear economy model-circular economy model gap ('a green gap' [6]) or they can facilitate the transition towards a more sustainable economy [7]. Recycling is one of those behaviors that can close the green gap and caption the power of the individual in the global challenge for achieving sustainability [8].

Food waste has a great significance in this context. Achieving food sustainability and reducing food waste are among the top challenges for achieving global sustainable development [9]. Food systems can be designed to be sustainable, economically efficient, valuing natural resources and generating very limited amounts of waste along the chain. Therefore, in order to reach sustainable development goals, it is necessary to promote, empower and accelerate the shift towards a more sustainable food production and consumption. One of the sustainable practices that can contribute to inspiring green consumption habits in society is urban agriculture. The latter has many advantages, since it contributes to food security in cities (SDG2), while bringing many benefits to the environment (SDG15) and to human health (SDG3) [10]. Reducing food waste and loss is one of the most important factors in mitigating the negative environmental impacts on at least three sustainability dimensions: carbon, land, and use [11]. The reduction of food loss and waste enhances the efficiency of natural resource utilization and reduces greenhouse gas emissions [9].

Fostering ecological knowledge and education in society influences consumption patterns, government policy-making and contributes to building a greener and more sustainable economy in the long term [12]. Making informed individual or collective decisions about consumption and production requires knowledge of the consequences of consuming more sustainable products and considering more sustainable production methods [13]. Understanding the role of the environmentaleconomic-social-cultural synergy in the individuals' decision making process and considering the consequences of consumption habits are key factors in creating the preference patterns that people have in their consumption choices [14-16]. In this context, not only policy makers, but also the top management of enterprises can play an important role in assuring sustainable development, as proved in a study concerning the case of the Visegrad countries [17].

Purchasing more, consuming more and then throwing away more, also known as consumerism [18], is one of the key drivers of the current unsustainable development [19]. In Europe, consumer household purchases (especially food, drinks, housing and private transportation) are responsible for about $70-80 \%$ of environmental impacts [20]. However, is the increasing environmental concern still leading to changes of the current consumer behaviors within the context of sustainable consumption?

New research trends concerning sustainable consumption behaviors have predominantly been conducted in developed countries like the United States, Germany, Italy and others [21]. Regarding this field of research, the trends often refer to topics such as energy consumption and efficiency, greenhouse gas emissions reduction, carbon and water footprint [22] growth in population and nominal GDP, mainly because they cannot be disregarded when designing a better, sustainable socio-economic development $[23,24]$. 
In 2019, the European Commission elaborated a new growth strategy which includes references to the sustainable consumption behaviors of EU citizens. With this new strategy, the European Commission aims to shape the future of the EU economy so that it should be resource-efficient and competitive, with no net emissions of greenhouse gases by 2050 — which will contribute to meeting the target of having economic growth decoupled from resource use [25]. This transition is no longer a preference, but a necessity, considering that, by 2050, the generation of annual waste is projected to increase by $70 \%$ globally [26] and the consumption of materials, including biomass, fossil fuels, minerals and metals is expected to double in the next 40 years [27].

In relation to sustainable consumption and production models, the new Circular Economy Action Plan for a cleaner and more competitive Europe includes initiatives meant to reshape consumption and business models to sustainable patterns in order for waste not to be produced in the first place [28]. The European Commission's proposals included in the 2030 Climate Target Plan consolidate the vision of the new Circular Economy Action Plan and go even further, by highlighting the need to stimulate the creation of 'green' jobs and continue with cutting greenhouse gas emissions and maintaining economic growth simultaneously [29].

The main objective of this research was to quantify the impact of biowaste recycling, greenhouse gas emissions and nominal GDP on energy productivity in the EU, as this impact indicates the convergence or divergence among the EU members in meeting the targets of the European Green Deal, the SDGs and the 2030 Climate Target Plan.

This paper brings contributions to the topic of sustainable consumption because it includes initial discussions regarding descriptive statistics and a correlation matrix including the significance levels of the specific indicators of sustainable consumption. Based on the initial findings resulting from the descriptive statistics analysis and the correlation matrix, together with the conducted literature review, this research is highly focused on designing a cross-sectional linear econometric model which validates the link between several sustainable consumption habits in the case of the EU members, taking 2018 as the year of reference for this study.

Additionally, an econometric model was designed in order to meet the research objective.

The novelty factor of this paper resides in the fact that the topic of sustainable consumption behavior was approached quantitatively—but still considering the importance of each particular observation included in the analysis, through the lens of the indicators specific to the SDG and of the circular economy. This is one of the reasons why the research focused on the contribution of each EU member to the convergence or divergence in achieving sustainable consumption behaviors, which also involve respecting the principles of the circular economy. The authors bring their unique contribution to empowering sustainable consumer behavior in the EU by designing an econometric model which estimates the link between energy productivity and economic power (GDP), biowaste recycling and the generation of greenhouse gas emissions. Considering the coefficient of determination of $74.21 \%$, the results of econometric model represent the foundation of the recommendations included in the conclusions section of this research paper.

\section{Materials and Methods}

Li et al. [30] emphasize how vital it is to explore the factors that determine renewable and sustainable energy consumption behaviors. Based on econometric modelling, the authors brought empirical evidence which confirm that the mix of income (GDP), human capital, energy productivity, energy prices and eco-innovation contributes to empowering sustainable consumption behaviors. Gilg et al. [31] conducted a research which highlights that specific demographic groups with particular behavioral attitudes are engaging differently in sustainability, yet this can be useful for policy makers for group targeting. Moreover, in his research, Trudel [32] argues that policymakers can significantly help and influence consumption behaviors on the road to sustainability. Consumers should be fully aware of the effects of their decision to dispose of recyclable products in the garbage or rather choose to recycle them in specially designed areas [33]. Batrancea et al. [34] reason that policymakers should act 
considering the importance of the elements of the adjusted net savings, with aim of increasing the GDP and hoping for a shift in the behavior consumption models, on their potential to become sustainable. Through this change, the greenhouse gas emissions would decrease, as they are linked to economic growth [35].

In the case of this study, the research method used for is econometric. The multiple cross-sectional linear regression methodology was applied in order to design a model meant to quantify the impact of economic development, sustainable development consumption behaviors and production patterns in the EU on energy efficiency.

Econometrics is a quantitative science which involves a harmonious statistical-economicalmathematical mix [36]. Econometrics includes techniques and methods for analyzing the dynamics of the variables in various fields of activity, as well as studying the interconnections among variables. The multiple cross-sectional linear regression method offers ways to establish the existence or inexistence of correlations between two types of variables: a dependent variable and multiple independent variables, as well as to quantify the proportion of the variance in the dependent variable that is predictable from among the independent variables [37].

The data used in this research were taken over from the Eurostat databases in September 2020. Table 1 contains relevant information regarding all the indicators used when constructing the cross-sectional linear multiple regression model. Moreover, Table 1 includes information regarding the reasons why each indicator was included in the econometric model and their associated variable nature in the model.

Table 1. Indicators used in the multiple cross-sectional linear regression model.

\begin{tabular}{|c|c|c|c|c|c|c|}
\hline $\begin{array}{l}\text { Item } \\
\text { No. }\end{array}$ & Abbreviation & $\begin{array}{l}\text { Indicator Codes } \\
\text { Assigned by } \\
\text { Eurostat }\end{array}$ & $\begin{array}{l}\text { Name of the } \\
\text { Indicator }\end{array}$ & $\begin{array}{l}\text { Unit of } \\
\text { Measure }\end{array}$ & $\begin{array}{l}\text { Variable } \\
\text { Type }\end{array}$ & $\begin{array}{l}\text { Reasons for Including } \\
\text { the Variable in the } \\
\text { Econometric Model }\end{array}$ \\
\hline 1 & $\mathrm{I}_{1}$ & SDG_07_30 & $\begin{array}{c}\text { Energy } \\
\text { productivity }\end{array}$ & $\begin{array}{c}\text { Euros per } \\
\text { kilogram } \\
\text { (oil equivalent) }\end{array}$ & Dependent & $\begin{array}{c}\text { Quantifies the } \\
\text { sustainable energy } \\
\text { consumption }[38,39] \\
\text { the progress made } \\
\text { towards achieving the } \\
\text { SDGs }[40,41]\end{array}$ \\
\hline 2 & $\mathrm{I}_{2}$ & CEI_WM030 & $\begin{array}{l}\text { Recycled } \\
\text { biowaste }\end{array}$ & $\begin{array}{l}\text { Kilograms } \\
\text { per capita }\end{array}$ & Independent & $\begin{array}{l}\text { Quantifies the nature of } \\
\text { consumption (food } \\
\text { waste, recycling habits) } \\
{[42,43] \text { in relation with }} \\
\text { the SDGs [44,45] }\end{array}$ \\
\hline 3 & $\mathrm{I}_{3}$ & SDG_13_10 & $\begin{array}{l}\text { Greenhouse } \\
\text { gas emissions }\end{array}$ & $\begin{array}{c}\text { Tons } \\
\text { per capita }\end{array}$ & Independent & $\begin{array}{l}\text { Quantifies the nature } \\
\text { and intensity of } \\
\text { consumption } \\
\text { habits toward achieving } \\
\text { the SDGs [46-48] }\end{array}$ \\
\hline 4 & $\mathrm{I}_{4}$ & NAMA_10_PC & Nominal GDP & $\begin{array}{c}\text { Euros } \\
\text { per capita }\end{array}$ & Independent & $\begin{array}{l}\text { Quantifies the influence } \\
\text { of the economic wealth } \\
\text { [49] on consumption } \\
\text { habits [50], correlated } \\
\text { with the SDGs [51,52] }\end{array}$ \\
\hline
\end{tabular}

Source: Authors' own conceptualization, based on literature review and on the indicators available online in the Eurostat database [53].

This research method is quantitative, based on cross-section statistic data. The indicators' values are considered only for the year 2018, for the EU-28 (UK was included in this study, as it was part of the EU in 2018 [54]), individually, with the exception of Ireland, Greece and Cyprus, due to data unavailability in the case of $\mathrm{I}_{2}$. However, discussions include references to the previously mentioned countries when approaching the rest of the indicators part of this study. The cross-section statistical data is characterized by multiple observations obtained at a certain single moment (in this study: the year 2018), referring to multiple entities (in this study: EU-28, with the exception of Ireland, Greece and Cyprus, due to data unavailability). The main limitation of this approach refers to the fact that 
this study does not encompass the historic data of the studied phenomena (the time series were excluded) [55] and it refers only to the reality of the year 2018.

The econometric model includes multiple variables: nominal GDP, as the fundamental socio-economic dimension; energy productivity, recycled biowaste and greenhouse gas emissions as the fundamental variables of consumption behaviors.

Energy productivity is measured in euro per kilogram (oil equivalent) and it is a relevant indicator in the context of sustainable consumption and production patterns, because it quantifies the amount of economic output produced per unit of gross available energy [56]. The latter represents the quantity of energy products necessary to satisfy the total demand of entities in the geographical area under consideration, EU-28 in the case of this research paper.

Energy productivity is included the EU SDGs indicator set [2]. The reason behind this is that energy productivity monitors the progress made towards SDG7 on cleaner, affordable and sustainable energy. Moreover, energy productivity is one of the indicators supposed to assess SDG12 progress, in relation with ensuring sustainable consumption and production patterns [57].

While SDG7 calls for providing easy access to modern energy services, for fostering energy efficiency and for increasing the share of renewable energy [58,59], SDG12 envisions sustainable consumption behavior and production patterns, highlighting resources efficiently, reducing global food and other waste, including biowaste, safely disposing of toxic waste, pollutants and others. SDG7 also refers to an accelerated transition to an affordable, reliable, and sustainable energy system, considering that countries have to facilitate access to and encourage clean energy research, promote investment in the energy infrastructure and in clean energy technology [60].

Additionally, there is a strong correlation between this indicator and the Europe 2020 strategy, which highlights the need for sustainable, inclusive and smart growth, while simultaneously reducing energy consumption and increasing energy efficiency [61-63].

Recycled biowaste is expressed in kilograms per capita. This indicator indirectly measured as the ratio of composted/methanized municipal waste (in mass unit) over the total population (in numbers) [64] is part of the Circular Economy indicator set [65] because it monitors the progress made towards a circular economy, from the perspective of waste management [66,67].

The EU Commission published the Circular Economy Package containing specific proposals regarding the EU waste legislation with the purpose of recycling and avoiding waste in the future [28]. Therefore, food waste management represents a topic of great attention, since up to $50 \%$ of the municipal solid waste is biogenic [68].

The food waste management-use of food or sustainable biomass production-compost production trio is a key factor for designing sustainable policies concerning the circular economy and the bio-economy, with direct obvious socio-economic and environmental implications. Within this context, a sustainable systems-thinking approach to policies is needed in order to minimize the impact of unsustainable consumption habits and population growth [69].

The trend in separately collecting and biologically treating biowaste (consisting of food waste, preponderantly) represents an essential feature of any sustainable waste management strategy [68]. Consequently, recycled biowaste is an important indicator, especially because it signals sustainable consumption behaviors. Moreover, it is significant in terms of composting/anaerobic digestion, as it tracks the contributions to the circular economy objectives for municipal waste [64].

The underlying assumption is that the only reasonable treatment of biowaste is composting or anaerobic digestion. Biotic resources must be returned to both the economy and the natural environment in an efficient and beneficial manner. R\&D results highlight promising improvement regarding the anaerobic digestion performances with direct implications on energy consumption behaviors [70].

The greenhouse gas emission indicator measures total national emissions, including carbon dioxide, methane, nitrous oxide, hydrofluorocarbons, perfluorocarbons, nitrogen trifluoride and sulfur hexafluoride, from all sectors of the emission inventories. The latter include international aviation, 
excluding land use, land use change and forestry. This indicator was calculated by obtaining the individual global warming potential of each of the gases previously mentioned and integrating the results into a single indicator expressed in carbon dioxide equivalents [71].

Part of the EU SDGs indicator set [2], the greenhouse gas emission indicator monitors the progress made concerning Goal 13, referring to climate action [72]. SDG13 aims to integrate climate change measures into national policies, strategies and planning [2]. Additionally, the greenhouse gas emission indicator can be found in the Europe 2020 strategy, where it is used to monitor the progress made towards the EU target of reducing the greenhouse gas emissions by at least $20 \%$ by 2020 (having the year 1990 as a baseline) [73].

The European Strategy for Low-Emission Mobility brings important contributions to reducing greenhouse gas emissions, especially in the case of the transport system in the EU, in relation with energy consumption and energy efficiency [74]. Furthermore, the Accelerating Clean Energy Innovation facilitates clean energy transition through targeted research and innovation [75].

Economic growth plays an important role in increasing energy efficiency and in helping the transition towards renewable energy consumption in the EU [76]. It has been explained that economic development must be considered when analyzing the efficiency of SDGs 2030 [77]. The relationship energy consumption-energy efficiency-economic growth provides insights regarding the role of energy consumption models in ensuring sustainable economic development. Under these conditions, suggestions for sustainable economic growth need to revolve around the promotion of energy efficiency, sustainable consumption behaviors and the development of green renewable energy - not only in the case of Europe, but also of other continents, such as Asia [78].

\section{Results}

Initially, each indicator mentioned in Table 1 and included in the econometric model was studied from the perspective of descriptive statistics. The next step was to elaborate the correlation matrix with significance levels ( $p$-value), which included all the previously mentioned indicators.

Afterwards, the econometric model constructed in the case of this research went systematically through many stages: specification, parameters setting, model testing and validation. This was achieved with the help of the EViews software, which is a tool used in quantitative research [79]. Estimating the parameters in the cross-section linear regression was facilitated by the method of least squares. The main tests performed on the econometric model were the $\mathrm{t}$-student test (with $\mathrm{H}_{0}$ : the coefficients did not differ significantly from 0 and $\mathrm{H}_{1}$ : the coefficients were significantly different from 0), Durbin-Watson for testing the autocorrelation of test errors, Jarque-Bera to test if the errors of the model followed (or not) a normal distribution. Additionally, the White test was applied to check the homoskedasticity or heteroskedasticity characteristic of the model residuals.

Regarding energy productivity in the EU-28, the raw data from Eurostat [53] were processed in Tableau Desktop 2020.3 and a map was elaborated in Figure A1 based on the values of this indicator. Moreover, the histrogram of energy productivity in the EU-28 and the descriptive statistics were elaborated taking the year 2018 as the reference year, both being included in Figure 1.

In 2018, on average, energy productivity in the EU-28 was 7.38 euros per kilogram of oil equivalent, with a standard deviation of 3.65 euros per kilogram, which represents almost $50 \%$ of the mean. The most productive country in the EU-28 concerning energy was Ireland, with an energy productivity of 18.8 euros per kilogram - which is 2.55 times greater than the mean. On the other hand, Bulgaria was at the bottom of the ranking of energy productivity, with only 2.41 euros per kilogram. As one can notice from the histogram in Figure 1, the distribution of energy productivity was positively skewed, the right tail was long and the mass of the distribution was concentrated on the left [80]. This was also validated by the value of skewness, 1.29 in this case. Kurtosis measures the peakedness or flatness of the distribution of a series and it signals the fact that the energy productivity distribution was peaked, leptokurtic, as the Kurtosis value exceeded the threshold of three, specific to a normal distribution [81]. Considering skewness (1.29) and kurtosis (4.84), two types of outliers can be noticed: 
Countries with high energy productivity when compared to the EU-28 mean, such as: Ireland (18.8), Denmark (14.81), Italy (10.12), Austria (9.83) and Germany (9.40).

Less productive countries from the standpoint of energy, such as: Bulgaria (2.41), Estonia (3.02), Malta (3.46), Czechia (4.30) and Poland (4.47).

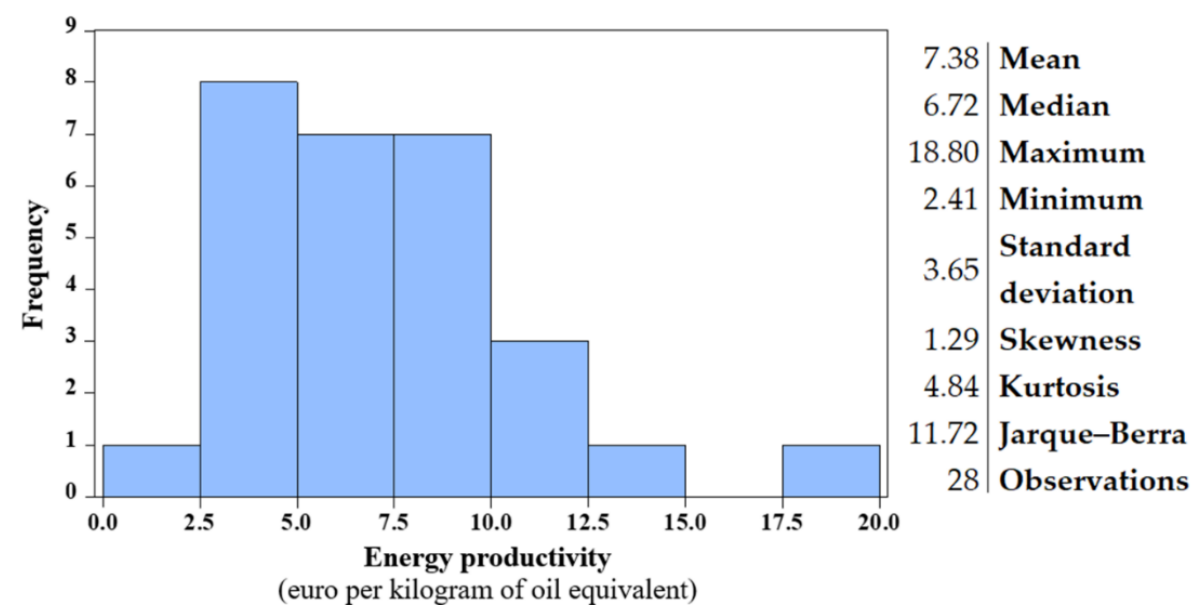

Figure 1. The histogram of energy productivity in the EU-28. Descriptive statistics, year 2018. Source: Authors' own results (raw data source: Eurostat [53], processed in EViews 10 Student Version Lite).

Jarque-Bera is a test statistic for testing if a series is normally distributed by measuring the difference between the skewness and kurtosis of the series and the normal distribution values. This difference should be zero in the case of a normally distributed series [82], yet this is not the situation for energy productivity.

With respect to the recycled biowaste in the EU, Figure A2 was elaborated with the aim of building a map which shows how the EU members perform when approaching this indicator. Additionally, the histogram of the recycled biowaste in the EU-28, with the exception of Ireland, Greece and Cyprus (due to data unavailability) and the descriptive statistics were elaborated taking the year 2018 as the reference year, both being included in Figure 2.

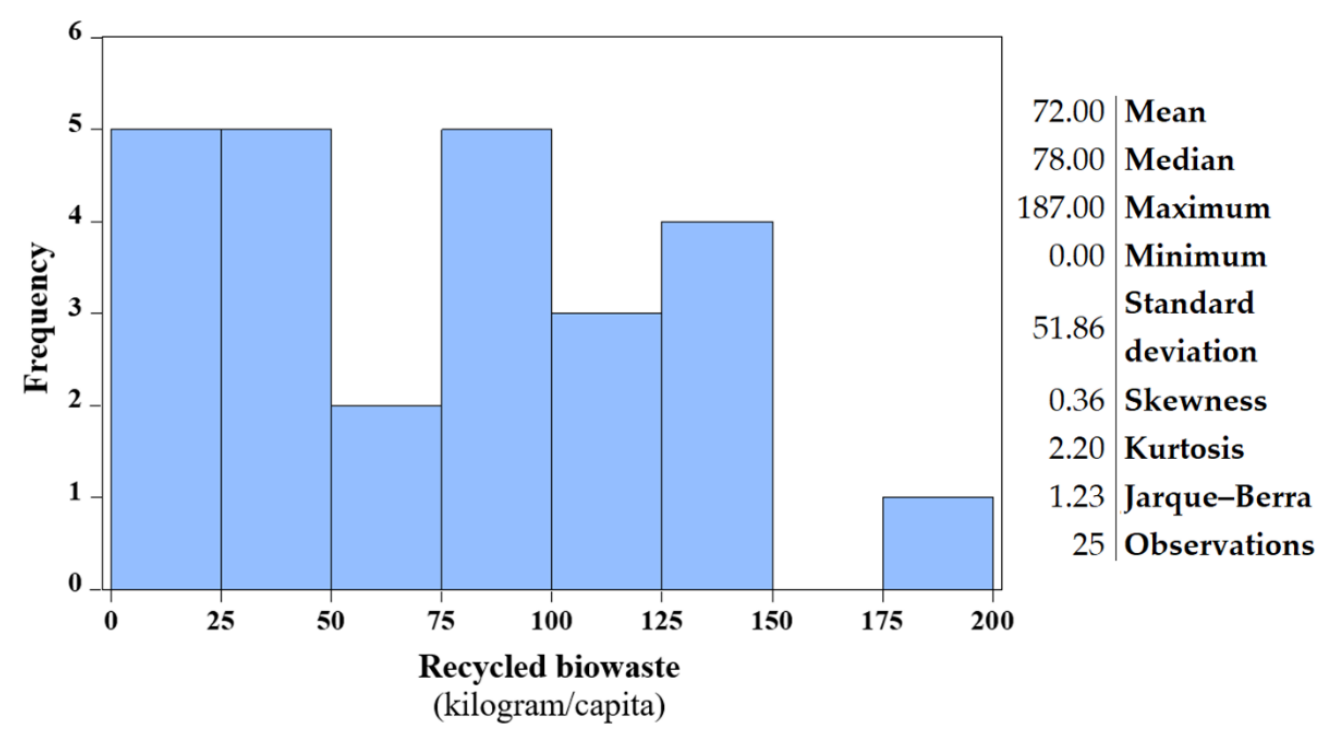

Figure 2. The histogram of the recycled biowaste in the EU-28, with the exception of Ireland, Greece and Cyprus, due to data unavailability. Descriptive statistics, year 2018. Source: Authors' own results (raw data source: Eurostat [53], processed in EViews 10 Student Version Lite). 
The mean of the 25 observations in terms of the recycled biowaste in 2018 was $72 \mathrm{~kg}$ per capita, with a standard deviation of 51.86 (72\% of the mean), which signals major discrepancies in the EU regarding the citizens' sustainable consumption model. This result is consolidated by the following evidence: the average Austrian citizen recycled $187 \mathrm{~kg}$ of biowaste in 2018, while the average Maltese citizen did not recycle even one kilogram of biowaste. Bulgaria and Romania could not pass the threshold of 10 recycled kilograms of biowaste in 2018. From the perspective of this indicator, Skewness (0.36) and Kurtosis (2.20) confirm that there are only few outlier countries which have successfully implemented measures to help the transition towards the circular economy: Austria, the Kingdom of the Netherlands, Denmark and Lithuania.

Regarding the greenhouse gas emissions in the EU-28, the map elaborated in Figure A3 illustrates the amount of greenhouse gas emissions generated by each EU-28 country, based on the values of this indicator. The histrogram and the descriptive statistics were elaborated taking the year 2018 as the reference year, both being included in Figure 3.

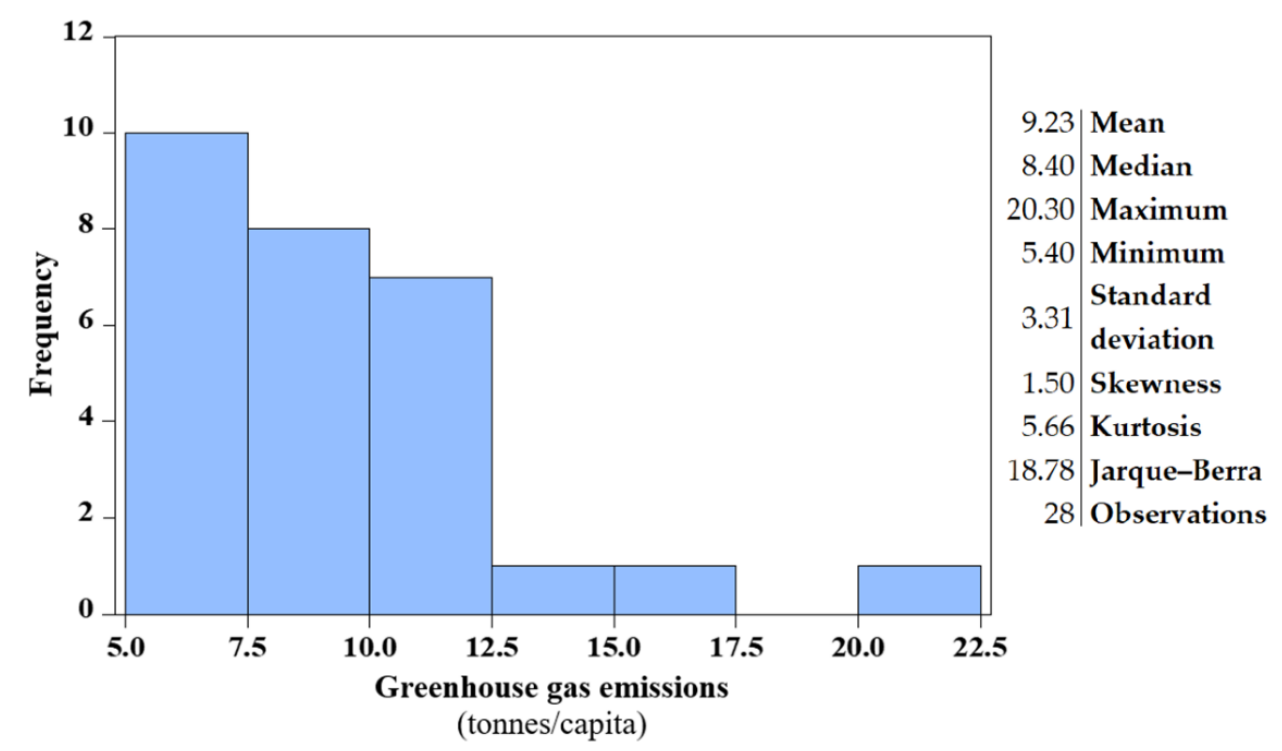

Figure 3. The histogram of greenhouse gas emissions in the EU-28. Descriptive statistics, year 2018. Source: Authors' own results (raw data source: Eurostat [53], processed in EViews 10 Student Version Lite).

In 2018, in the EU-28, the mean of the greenhouse gas emissions was 9.23 tons per capita, with a standard deviation of 3.31 (35.86\% of the mean). One of the limitations of the descriptive statistics in the case of this indicator is the fact that the mean of the 28 observations was artificially increased by Luxembourg (20.30 tons of greenhouse gas emissions per capita, the country situated at the top of the ranking), because its population $(602,005)$ represented only $0.11 \%$ of the total population in the EU-28 in 2018 [50], while on the other hand, the population of Czechia $(10,610,055)$ represented $2.07 \%$ of the EU-28's total population in 2018 [53], with 12.20 tons of greenhouse gas emissions per capita, on average. Even though Luxembourg had the highest value of greenhouse gas emissions per capita in the EU-28, it must be considered that there were other big players, such as Czechia, with considerable contributions to the generation of greenhouse gas emissions in the EU. Besides Luxembourg (20.30), Estonia (15.30), Ireland (13.20), Czechia (12.20) and the Netherlands (11.60) were the top five countries with the highest generation of greenhouse gas emissions per capita in the EU, while Sweden (5.40), Malta (5.50), Romania (6.00), Croatia (6.00) and Latvia (6.30) placed themselves at the bottom of the ranking. Skewness (1.50) and Kurtosis (5.66) highlight the convergence in the EU-28 towards generating as few greenhouse gas emissions as possible.

With respect to the nominal GDP in the EU-28 (2018), Figure A4 was designed with the purpose of highlighting the differences between the EU-28 members when analyzing the values of this indicator. 
Moreover, the histogram and the descriptive statistics were elaborated taking the year 2018 as the reference year, both being included in Figure 4.

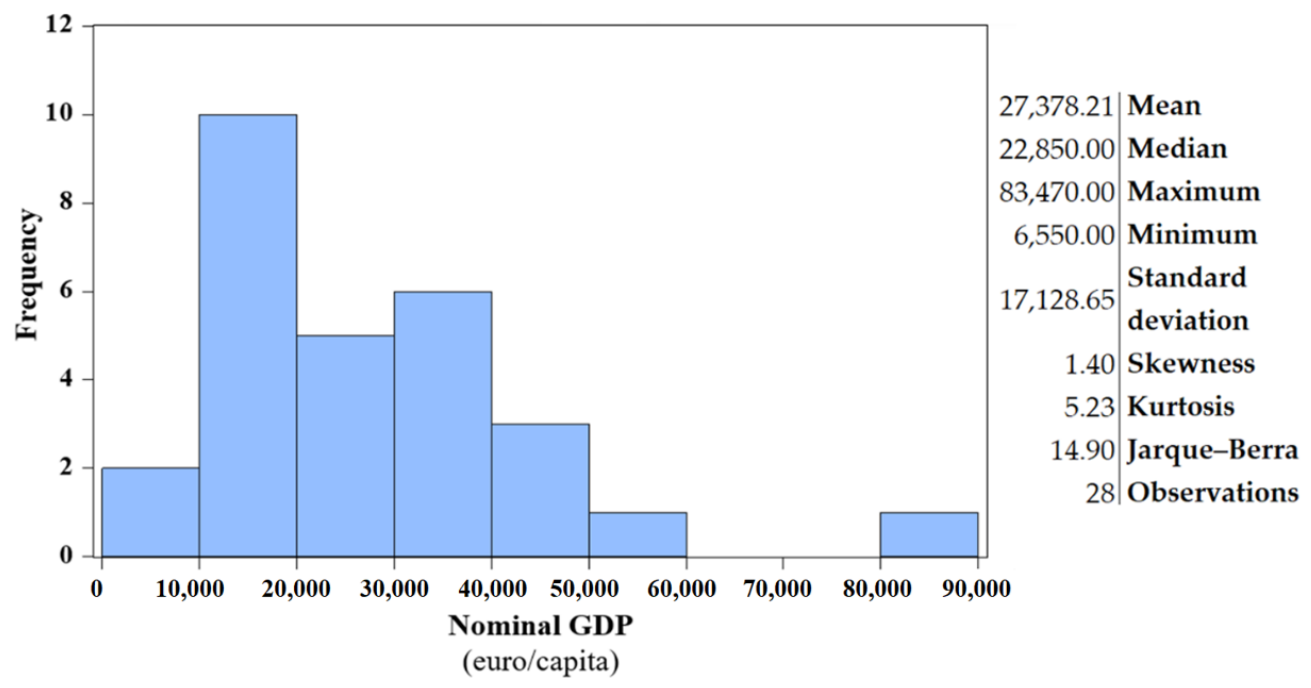

Figure 4. The histogram of the nominal GDP in the EU-28. Descriptive statistics, year 2018. Source: Authors' own results (raw data source: Eurostat [53], processed in EViews 10 Student Version Lite).

The average nominal GDP in the EU-28 was 27,378.21 euro in 2018, with a standard deviation of $17,128.65$-which represents $62.56 \%$ of the mean, therefore highlighting discrepancies among the EU-28 members. On the one hand, Luxembourg and Ireland are among the top countries regarding the nominal GDP (83,470 and 57,780 euro) and the greenhouse gas emissions (20.30 and 13.20 tons per capita) and, on the other hand, countries such as Bulgaria (6550 euro per capita) and Romania (8740 euro per capita) are at the bottom of the ranking, deeply affected in terms of the economic power of the individual, even though they are not necessarily generating a lot of greenhouse gas emissions (8.30 tons per capita in the case of Bulgaria and 6.00 in the case of Romania, below the EU-28 average of 9.23 tons per capita). Skewness (1.40), kurtosis (5.23) and Jarque-Bera confirm that this series is not normally distributed, an unfavorable situation from a socio-economic perspective. However, abnormality would be desirable if the distribution was to be negatively skewed and leptokurtic, because then that would signal large numbers of EU members having high values of the nominal GDP and only few countries that would have to catch up.

In order to follow the normal flow of the research methodology, the correlation matrix with significance levels was included in Table 2 concerning all the analyzed indicators.

Table 2. The correlation matrix with significance levels ( $p$-value) in case of the econometric model variables, reference year: 2018, EU-28 with the exception of Ireland, Greece and Cyprus, due to data unavailability.

\begin{tabular}{ccccc}
\hline & $\begin{array}{c}\text { Energy } \\
\text { Productivity }\end{array}$ & $\begin{array}{c}\text { Recycled } \\
\text { Biowaste }\end{array}$ & $\begin{array}{c}\text { Greenhouse } \\
\text { Gas Emissions }\end{array}$ & $\begin{array}{c}\text { Nominal } \\
\text { GDP }\end{array}$ \\
\hline $\begin{array}{c}\text { Energy productivity } \\
p \text {-value }\end{array}$ & 1.000 & & & \\
Recycled biowaste & - & & & \\
$p$-value & 0.750 & 1.000 & & \\
Greenhouse gas emissions & 0.000 & - & 1.000 & \\
$p$-value & 0.130 & 0.259 & - & 1.000 \\
Nominal GDP & 0.537 & 0.212 & 0.564 & - \\
$p$-value & 0.738 & 0.674 & 0.003 & \\
\hline
\end{tabular}

Source: Authors' own results (raw data source: Eurostat [53], processed in EViews 10 Student Version Lite). 
The results in the correlation matrix signal the fact that energy productivity has a strong positive correlation with the recycling of biowaste (0.75) in the case of the $28 \mathrm{EU}$ members (2018) and the data is statistically significant, considering the $p$-value of 0.00 . The situation is similar in the case of the energy productivity-nominal GDP relationship (strong positive correlation, 0.738 ) and in the case of the recycling of biowaste-nominal GDP relationship (moderate positive correlation, 0.674 ). Greenhouse gas emissions are moderately correlated with the nominal GDP (0.564), with a $p$-value (0.003) that signals statistical significance [83].

Taking into account the results obtained so far, the multiple cross-sectional linear regression method was applied and the econometric model was constructed in Table 3, considering "energy productivity" as the dependent variable, while "recycled biowaste", "greenhouse gas emissions" and "nominal GDP" were considered independent variables.

Table 3. The results of the cross-sectional multiple linear regression.

\begin{tabular}{|c|c|c|c|c|}
\hline \multicolumn{5}{|c|}{ Estimation Command } \\
\hline \multicolumn{5}{|c|}{ LS SDG_07_30 C CEI_WM030 SDG_13_10 NAMA_10_PC } \\
\hline \multicolumn{5}{|c|}{ Estimation Equation } \\
\hline \multicolumn{5}{|c|}{ SDG_07_30 $=\mathrm{C}(1)+\mathrm{C}(2) \times$ CEI_WM030 $+\mathrm{C}(3) \times$ SDG_13_10 $+\mathrm{C}(4) \times$ NAMA_10_PC $+\varepsilon$} \\
\hline \multicolumn{5}{|c|}{ Substituted Coefficients } \\
\hline \multicolumn{5}{|c|}{ SDG_07_30 $=4.9101+0.0227 \times$ CEI_WM030 $+(-0.3171 \times$ SDG_13_10 $)+0.0001 \times$ NAMA_10_PC $+\varepsilon$} \\
\hline \multicolumn{5}{|c|}{$\begin{array}{l}\text { Dependent Variable: SDG_07_30 } \\
\text { Method: Least Squares } \\
\text { Observations: EU-28 with the exception of Ireland, Greece and Cyprus, due to data unavailability } \\
\text { Reference year: } 2018\end{array}$} \\
\hline Variable & Coefficient & Standard Error & t-Statistic & Prob. \\
\hline C & 4.91012 & 1.0063 & 4.8794 & 0.0001 \\
\hline CEI_WM030 & 0.02270 & 0.0090 & 2.5203 & 0.0199 \\
\hline SDG_13_10 & -0.31716 & 0.1237 & -2.5636 & 0.0181 \\
\hline NAMA_10_PC & 0.00012 & 0.0000 & 3.7744 & 0.0011 \\
\hline $\mathrm{R}^{2}$ & 0.74213 & \multicolumn{2}{|c|}{ Mean dependent var } & 6.94040 \\
\hline Adjusted $\mathrm{R}^{2}$ & 0.70529 & \multicolumn{2}{|c|}{ S.D. dependent var } & 3.05303 \\
\hline S.E. of regression & 1.65741 & \multicolumn{2}{|c|}{ Akaike info criterion } & 3.99403 \\
\hline Sum squared resid & 57.68690 & \multicolumn{2}{|c|}{ Schwarz criterion } & 4.18905 \\
\hline Log likelihood & -45.92539 & \multicolumn{2}{|c|}{ Hannan-Quinn criter. } & 4.04812 \\
\hline F-statistic & 20.14519 & \multicolumn{2}{|c|}{ Durbin-Watson stat } & 1.27565 \\
\hline Prob (F-statistic) & & \multicolumn{2}{|c|}{0.00000} & \\
\hline
\end{tabular}

$\mathrm{R}^{2}$ indicates that $74.21 \%$ of the variation of the energy productivity was explained by the recycled biowaste, greenhouse gas emissions and nominal GDP. In order to mitigate the mechanical increase in the coefficient of determination [84], Adjusted $\mathrm{R}^{2}$ validated the model, taking into account that there was a drop only from $74.21 \%$ to $70.52 \%$ between the coefficient of determination and the Adjusted $R^{2}$. The Durbin-Watson statistic, a test for autocorrelation in the residuals of the model, indicates that successive error terms were slightly positively correlated, because the value corresponding to this statistic is 1.27565 . However, the value is considered acceptable, as the number of observations was limited [85].

The Student- $t$ values of the parameters are calculated in the t-Statistic column. In the case of this econometric model, the values were below the 0.05 threshold for all the variables included in the model. Therefore, $\mathrm{H}_{0}$ is rejected, meaning that the parameters of the variables significantly differ from 0 and each variable has a meaningful addition to the model, because changes in the predictor's value are related to changes in the independent variables. This result signals the fact that sustainable consumption behaviors (i.e., energy productivity) can be fostered by implementing strategies that have 
direct implications on biowaste recycling, greenhouse gas emissions and that consider the role of the economic power of the individual in the context of consumption preferences.

Considering the equation of the econometric model, should the recycled biowaste per capita in a country be situated around the mean, $72 \mathrm{~kg}$ for example, and the same for the greenhouse gas emissions (9.23 tons per capita) and the nominal GDP (27,378.21 euro), then this explains an energy productivity in the respective country of 6.9026 euro per kilogram of oil equivalent (calculated as: $4.91012+(0.02270 \times 72)+(-0.31716 \times 9.23)+(0.00012 \times 27,378.21))$. This equation signals the fact that sustainable consumption behaviors (e.g., energy productivity) is strongly connected with the amount of recycled biowaste and with the economic power of the individual, while it is simultaneously and negatively impacted by the amount of greenhouse gas emissions generated.

According to Table 4, the confidence intervals for the variables included in the econometric model confirm the following: with a $90 \%$ confidence rate, should the average biowaste per capita recycled in the EU supposedly increase to $100 \mathrm{~kg}$, the greenhouse gas emission decrease to 8 tons per capita and the average nominal GDP increase to 30,000 euro, then it is estimated that the respective locality has a corresponding energy productivity situated in the following interval: 1.75816 euro per kilogram of oil equivalent lower bound, calculated: $3.17856+(0.00720 \times 100)+(-0.53005 \times 8)+(0.00007 \times 30,000))$ and 15.02852 euro per kilogram of oil equivalent upper bound, calculated as: $6.64168+(0.03821 \times 100)$ $+(-0.10427 \times 8)+(0.00018 \times 30,000)$.

Table 4. The confidence intervals of the econometric model.

\begin{tabular}{cccccccc}
\hline \multirow{2}{*}{ Variable } & Coefficient & \multicolumn{2}{c}{$\mathbf{9 0 \%}$ Confidence } & \multicolumn{2}{c}{$\mathbf{9 5 \%}$ Confidence } & \multicolumn{2}{c}{$\mathbf{9 9 \%}$ Confidence } \\
\cline { 3 - 8 } & & $\begin{array}{c}\text { Lower } \\
\text { Bound }\end{array}$ & $\begin{array}{c}\text { Upper } \\
\text { Bound }\end{array}$ & $\begin{array}{c}\text { Lower } \\
\text { Bound }\end{array}$ & $\begin{array}{c}\text { Upper } \\
\text { Bound }\end{array}$ & $\begin{array}{c}\text { Lower } \\
\text { Bound }\end{array}$ & $\begin{array}{c}\text { Upper } \\
\text { Bound }\end{array}$ \\
\hline C & 4.91012 & 3.17856 & 6.64168 & 2.81743 & 7.00281 & 2.06095 & 7.75928 \\
CEI_WM030 & 0.02270 & 0.00720 & 0.03821 & 0.00397 & 0.04144 & -0.00280 & 0.04821 \\
SDG_13_10 & -0.31716 & -0.53005 & -0.10427 & -0.57445 & -0.05987 & -0.66746 & 0.03313 \\
NAMA_10_PC & 0.00012 & 0.00007 & 0.00018 & 0.00005 & 0.00019 & 0.00003 & 0.00021 \\
\hline
\end{tabular}

Source: Authors' own results (raw data source: Eurostat [53], processed in EViews 10 Student Version Lite).

With a $95 \%$ confidence rate, should the average biowaste per capita recycled in the EU supposedly increase to $100 \mathrm{~kg}$, the greenhouse gas emission decrease to 8 tons per capita and the average nominal GDP increase to 30,000 euro, then it is estimated that the respective locality has a corresponding energy productivity situated in the following interval: 0.11883 euro per kilogram of oil equivalent lower bound $2.81743+(0.00397 \times 100)+(-0.57445 \times 8)+(0.00005 \times 30,000))$ and 16.36785 euro per kilogram of oil equivalent upper bound, calculated as: $7.00281+(0.04144 \times 100)+(-0.05987 \times 8)+(0.00019 \times 30,000))$.

In order to have a more in-depth approach of the observations included in the econometric model (EU-28 with the exception of Ireland, Greece and Cyprus, due to data unavailability) and to continue validating it, the residuals were studied and the White Test for heteroskedasticity was performed with $\mathrm{H}_{0}$ of homoskedasticity. The results and details are included in Table 5.

Table 5. Testing the residuals of the econometric model for heteroskedasticity.

\begin{tabular}{cccc}
\hline \multicolumn{4}{c}{ The White Test for Heteroskedasticity } \\
\hline \multicolumn{4}{c}{ Null Hypothesis: Homoskedasticity } \\
\hline F-statistic & 0.95042 & Prob. $F(5,36)$ & 0.51317 \\
Obs $\times \mathrm{R}^{2}$ & 9.07901 & Prob. $\chi^{2}(5)$ & 0.43001 \\
Scaled explained SS & 6.36609 & Prob. $\chi^{2}(5)$ & 0.70279 \\
\hline
\end{tabular}

Source: Authors' own results (raw data source: Eurostat [53], processed in EViews 10 Student Version Lite).

According to the White Test results, we accept homoskedasticity, taking into account that F-statistic is 0.95042 , with an associated probability above the 0.05 threshold [83]. In the case of this model, 
the variance of the residuals was constant and did not vary much as the value of the predictor variable changes - a finding that validates the designed econometric model.

Going even further with the analysis of the residuals, Table 6 was constructed and it contains the residual plot of the econometric model. Moreover, it provides a larger perspective on the impact of each observation towards achieving an ideal $\mathrm{R}^{2}$, because Table 6 contains the ranking of the observations with a share in the sum of the residuals (in modulum) greater than $5.00 \%$.

Table 6. The residuals and residual plot of the econometric model. Observations with a share in the sum of the residuals (in modulum) greater than $5.00 \%$.

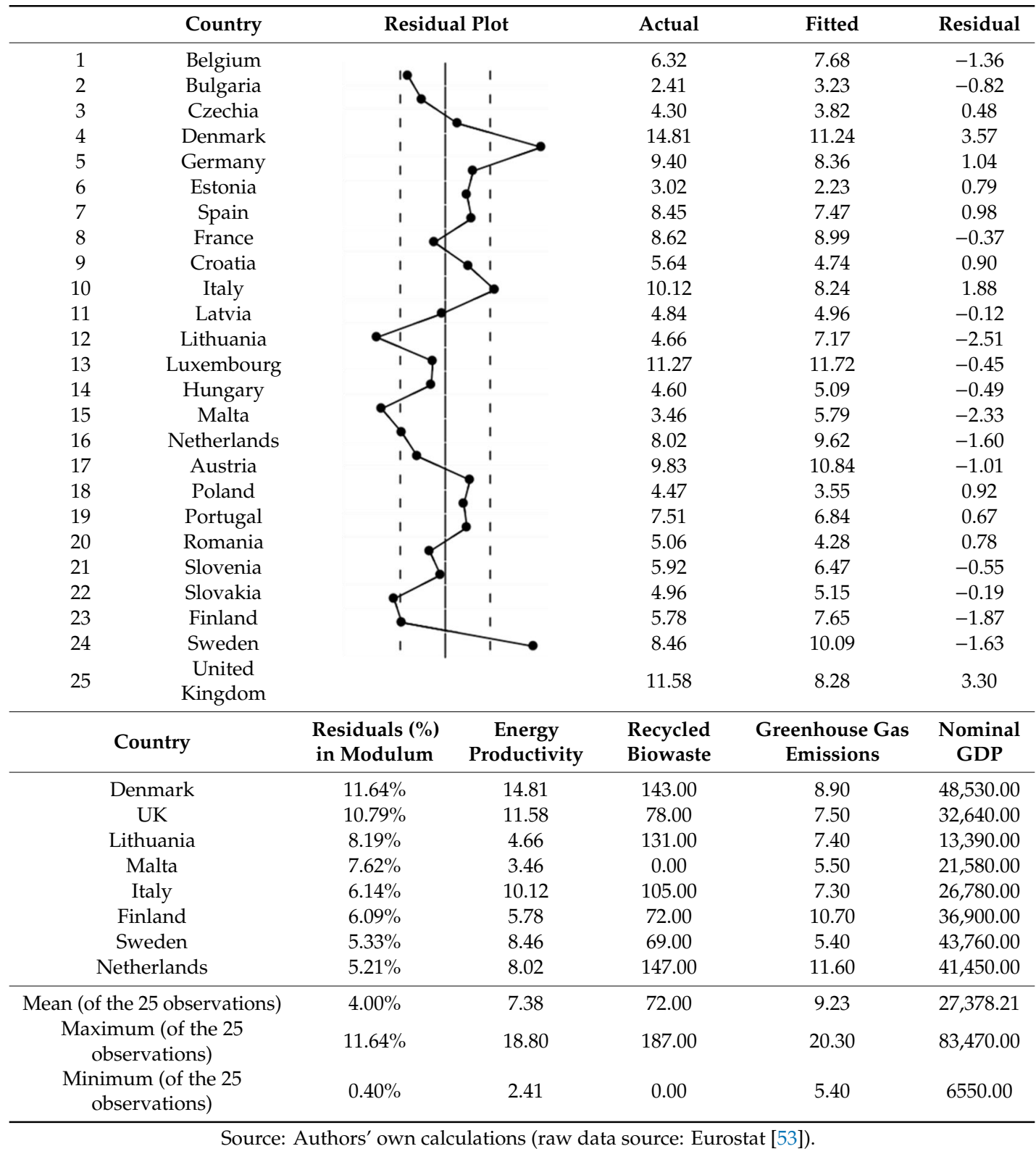

Denmark, UK, Lithuania, Malta, Italy, Finland, Sweden and the Netherlands were the observations that contributed the most to lowering the $\mathrm{R}^{2}$, because their residual values in modulum reported to the sum of residuals in modulum were the greatest among all the 25 observations. This is caused by various reasons, but, to be more specific, it is necessary to study the deviation from the mean per variable and per observation, as this highlights discrepancies and outliers in the model, as described 
by the residual plot in Table 6. Consequently, Figure 5 was designed to indicate the reasons why there are outliers in the designed econometric model.

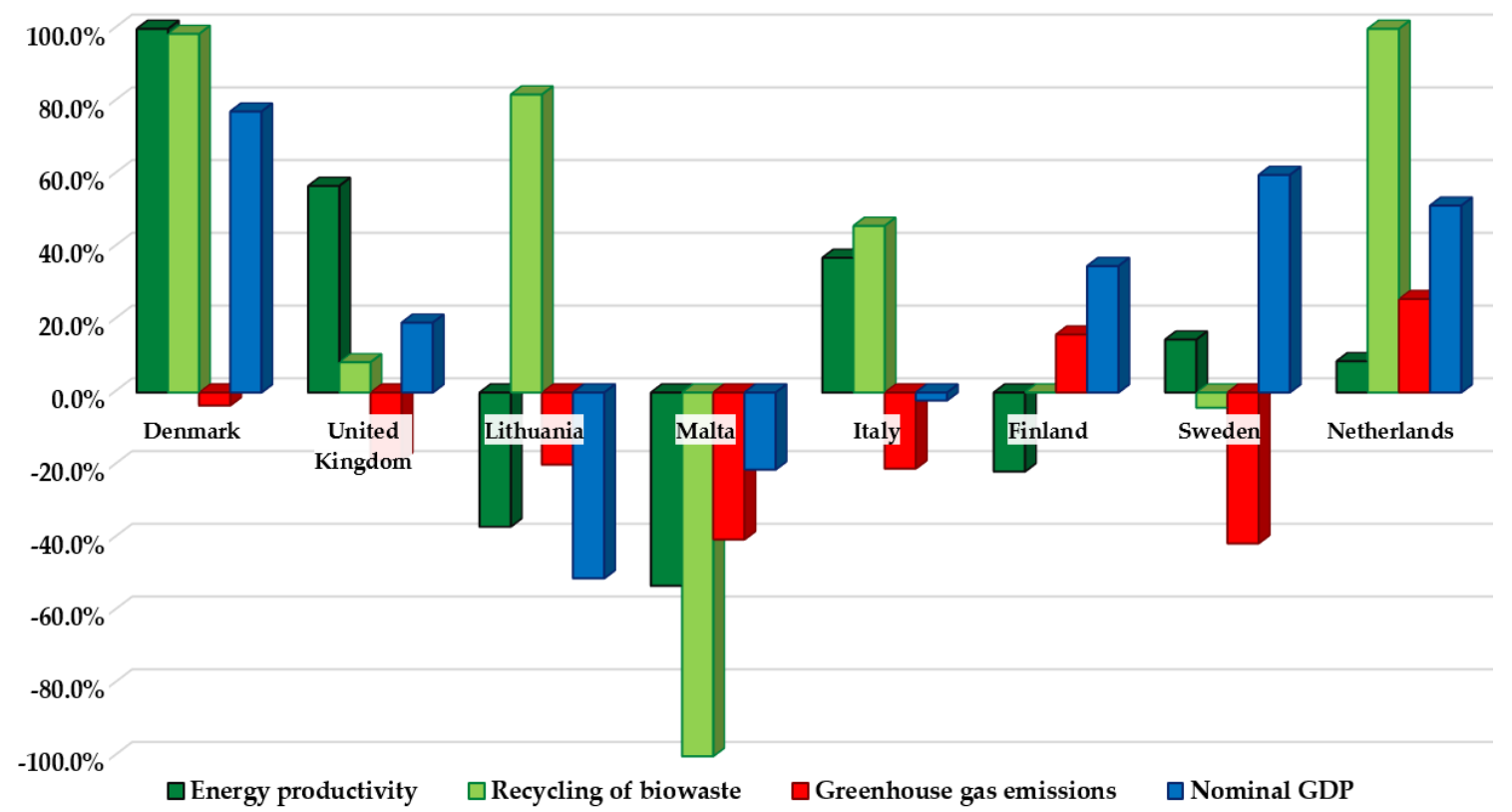

Figure 5. The deviation from the mean, per variable, in the case of the observations with a share in the sum of the residuals (in modulum) greater than 5.00\%. Source: Authors' own conceptualization (raw data source: Eurostat [53]).

When reported to the mean of the 25 observations included in the econometric model, Denmark was the absolute winner when analyzing sustainable consumption behaviors, because it had double the energy productivity than that of the mean and the situation was similar when analyzing the amount of biowaste recycled. Not only that, but Denmark also produced fewer greenhouse gas emissions $(-3.56 \%)$ and the Danish citizens were $77.26 \%$ more economically powerful when compared to the rest of the countries included in the model. On the contrary, Malta was one of the EU-28 members which encountered a lot of issues-energy productivity was 53.1\% weaker, Maltese citizens did not recycle biowaste, and their economic power was $21.18 \%$ weaker when reported to the mean of the 25 observations. However, Malta generated fewer greenhouse gas emissions (40.40\% less to be more specific). The situation of the UK was similar to that of Denmark. Lithuania, Italy and the Netherlands generated high residual values in the model because of a favorable situation: their citizens recycled a lot of biowaste when reported to the mean. Sweden contributed significantly to the generation of high residual values in the econometric model because Swedish citizens had high economic power and generated low values of greenhouse gas emissions when reported to the mean. On a small scale, this situation was similar in the case of Finland, only that energy productivity was much lower.

\section{Discussion}

Humanity faces an immanent need to transform consumption behaviors and production patterns from the ones characterized by unsustainable or hybrid practices to green, sustainable, equitable practices, appropriate from multiple perspectives, but having the environmental dimension among the top priorities. This involves reshaping consumption habits and lifestyles in accordance with policies and practices that empower energy efficiency, recycling, circular economy principles, measures meant to decrease greenhouse gas emissions.

The growing population impacts the demand and supply of food [86], fuel, consumer products, the intensity with which goods and services are produced. It also generates an increase in waste generation and greenhouse emissions, in the case of unsustainable consumption and production 
patterns. In the spirit of sustainable consumption and production behaviors, businesses need to be the engines of the circular economy [87]. As unsustainable consumption patterns are negatively affecting the environment, changes in the production models adopted by businesses all over the world will determine changes in consumption behaviors towards sustainability. Consequently, in order to empower sustainable consumption in society, it is important to actively engage consumers in mutual dialogue - but more importantly, to provide examples of actions taken in the sense of building a greener and sustainable economy. Companies can act as the first vectors of change and can influence consumption behaviors in society by reshaping the demand structures.

The transition towards efficient consumption (wasting less), high quality consumption (carefully selecting goods and services, based on individual preferences and standards), and sufficient consumption (in terms of quantity) demonstrates sustainable lifestyle approaches [88]. Such characteristics of a sustainable consumption behavior should be consolidated by collaborative consumption models [89], such as sharing, swapping, trading of goods and services.

As demonstrated in this study concerning the situation of EU-28 in 2018, there were few outlier countries which registered high values of greenhouse gas emissions when reported to the mean, this situation being similar to that of the distribution of energy efficiency. These results highlight discrepancies among the EU members in terms of achieving the goals of sustainable consumption at the same time. Some countries such as Denmark, Sweden and Italy are closer to meeting the goals of sustainable development in the EU, while Malta is facing major problems in this regard. Even though this study highlighted the correlation between sustainable consumption behaviors and the economic power of the individual, more specifically the fact that societies with high purchase power in the EU tend to adopt sustainable consumption habits faster (such as Denmark), there are examples of countries that are not as wealthy as others, but which still manage to adopt sustainable consumption habits (like Lithuania). The distributions of the greenhouse gas emissions and of the nominal GDP are also similar, signalling two kind of outliers in the EU-28:

- one that implies the following patterns: sustainable consumption models (low values of greenhouse gas emissions per capita) with high economic power per individual (high values of the nominal GDP)— the case of Denmark, Sweden, France and Italy

- another one that implies the following patterns: unsustainable consumption models (high values of greenhouse gas emissions per capita) with deteriorated individual economic power (small values of the nominal GDP)— the case of Estonia, Poland and Czechia.

As far as biowaste recycling is concerned in the EU-28, this circular economy indicator is connected with energy efficiency and with the economic power of the individuals. Countries such as Ireland, Denmark, Norway, Luxembourg and Italy are at the top of the list when ranking energy efficiency and the nominal GDP. These countries are also the leaders of biowaste recycling, with the exception of Norway-which is situated just at the mean of the EU-28. Austria is the big winner of biowaste recycling, with 187 recycled kilograms per capita, which is 2.59 times greater than the mean in 2018, at the level of EU-28. Even though Austria is also energy efficient, it is not as efficient as Denmark or Norway. In this context, further research directions can focus on studying trends in terms of the evolution of the indicators included in this research paper. This could highlight emerging countries when analyzing European sustainable consumption behavior trends, as well as the convergence or divergence of the effects of implementing environmental policies in the EU. The econometric model constructed in this paper can be used when analyzing the sustainable consumption patterns in relation to energy efficiency, greenhouse gas emissions and nominal GDP in the case of other localities, cities, regions, countries, etc. Moreover, the model can be updated when more recent data become available and can be upgraded by including more indicators. 


\section{Conclusions}

Empowering sustainable consumption behaviors and production patters in the EU by greening the economic development through reducing the amount of greenhouse gas emissions, recycling and focusing on energy productivity are just some directions that can improve the quality of life in the EU and that contribute to stepping into a cleaner and wealthier future. On a voluntary basis, EU members are trying to mitigate their negative impact on the environment, while harmonizing their economic, social, and environmental development towards sustainability. Through the SDGs, significant measures and actions are recommended in order to ensure sustainable development, consumption behaviors included.

Reducing energy consumption and greenhouse gas emissions is possible, especially when considering efficiency. Decision makers in the field of sustainable development should take advantage of this synergy. Regarding the citizens, they should reexamine their way of living, more particularly the way they consume goods and services. Were the latter produced in a sustainable manner? Are they easily recyclable? Do they observe the principles of the circular economy? These are just some questions to be considered when purchasing, because through their preferences and consumption behaviors, consumers play a central role in reshaping the economy towards sustainability.

The collection and use of biowaste from households, food and beverage industry restaurants, slaughterhouses and other sources represent a central component in the development of a more responsible society with sustainable consumption behaviors. If biowaste recycling becomes generally accepted at the level of society as a solution in order to achieve a more circular economy and as a practice that generates eco-friendly habits, then this would translate into many socio-economic and environmental benefits. Additionally, regarding agriculture, the implementation of such practices has many benefits, especially when considering the results of biowaste recycling (compost) and the cleaner approach to doing agriculture.

Through its strategies and policies, the EU supports the transition towards a resource-efficient, low-carbon economy, sustainable consumption models and production patterns. This approach ensures sustainable socio-economic growth. Relevant legislation has been proposed and adopted in order to support this transition. According to the 2030 Climate Target Plan, the European Commission proposes to rethink the EU ambition of reducing greenhouse gas emissions from $50 \%$ to at least $55 \%$ below the 1990 levels by 2030 - therefore highlighting once more the importance of empowering sustainable consumption models and production patterns.

In order for the European Green Deal to be delivered, EU citizens play an essential role. Mutual understanding between EU citizens and EU institutions is highly valuable in this context, but another aspect that needs to be considered in order to meet the European Green Deal targets is rethinking and adapting EU policies in order to ensure the transition towards clean energy supply across the EU economy, industry, transport, agriculture and other sectors, but most importantly-to empower sustainable consumption and production models.

Achieving the $55 \%$ reduction target in the case of greenhouse gas emissions would result in a new and greener energy mix in the EU. Correlated with the emergence of fostering sustainable consumption models, the European Commission estimated that coal consumption would be reduced by more than $70 \%$, oil consumption by $30 \%$ and gas consumption by $25 \%$ respectively, by 2030 , having the year 2015 as the point of reference. Additionally, renewable energy would increase its share: $38 \%$ to $40 \%$ of gross final consumption by 2030. The European citizen is the engine of change. By adopting sustainable consumption models, European citizens can lead the trend towards a balanced path towards climate neutrality by 2050 .

The main limitation of this research resides in the fact that the data included in the econometric model refers only to the year 2018 and provides deeper perspectives from a structural point of view but ignores trends and the evolution of the indicators. Taking this into account, further studies could focus on sustainable consumption behaviors from the perspective of indicators included in this study 
and, more importantly, research their dynamic in time and possibly determine trends. Additionally, the research could also be extended by considering more geographical locations.

Author Contributions: M.C. and S.R.P. conceptualized this manuscript; M.C. consolidated the literature review, prepared the database, methodology, software validation and wrote this manuscript; S.R.P., M.D., R.P., M.C. and A.-M.P. reviewed the manuscript and assisted in writing and finalizing the manuscript. All authors have read and agreed to the published version of the manuscript.

Funding: This work was cofinanced from the European Social Fund through Operational Programme Human Capital 2014-2020, project number POCU/380/6/13/125015. “Development of entrepreneurial skills for doctoral students and postdoctoral researchers in the field of economic sciences".

Conflicts of Interest: The authors declare no conflict of interest.

\section{Abbreviations}

\begin{tabular}{|c|c|}
\hline (Adjusted) $\mathrm{R}^{2}$ & The (adjusted) coefficient of determination \\
\hline EU & European Union \\
\hline EU-28 & The 28 Members of the European Union in 2019 \\
\hline GDP & Gross domestic product \\
\hline $\mathrm{H}_{0}$ & The null hypothesis \\
\hline $\mathrm{H}_{1}$ & The alternative hypothesis \\
\hline $\begin{array}{l}\mathrm{I}_{1} \\
\text { SDG_07_30 }\end{array}$ & Energy productivity \\
\hline $\begin{array}{l}\mathrm{I}_{2} \\
\text { CEI_WM030 }\end{array}$ & Recycled biowaste \\
\hline $\begin{array}{l}\mathrm{I}_{3} \\
\text { SDG_13_10 }\end{array}$ & Greenhouse gas emissions \\
\hline $\begin{array}{l}\mathrm{I}_{4} \\
\text { NAMA_10_PC }\end{array}$ & Nominal gross domestic product \\
\hline R\&D & Research and development \\
\hline SDG & Sustainable Development Goal \\
\hline UK & $\begin{array}{l}\text { United Kingdom (The United Kingdom of Great } \\
\text { Britain and Northern Ireland) }\end{array}$ \\
\hline
\end{tabular}




\section{Appendix A}
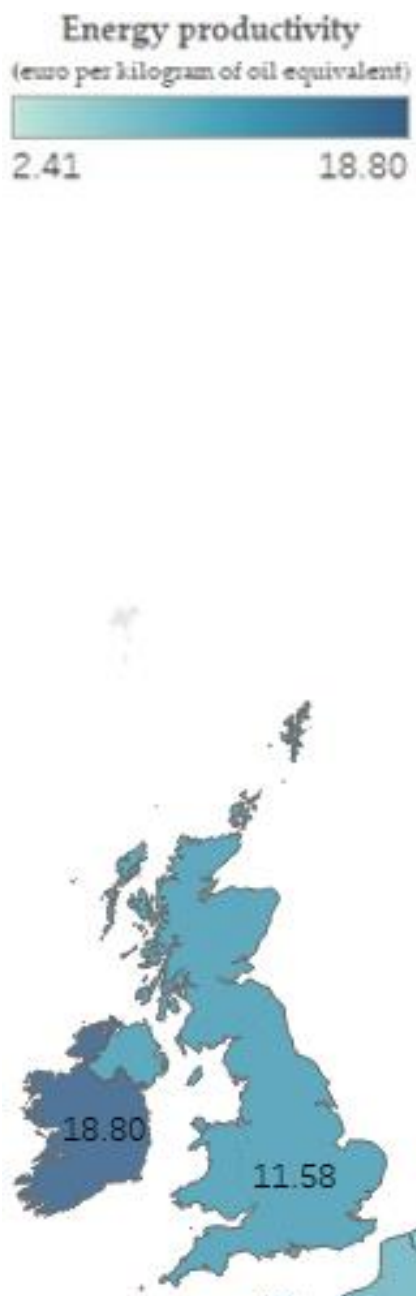

8.80

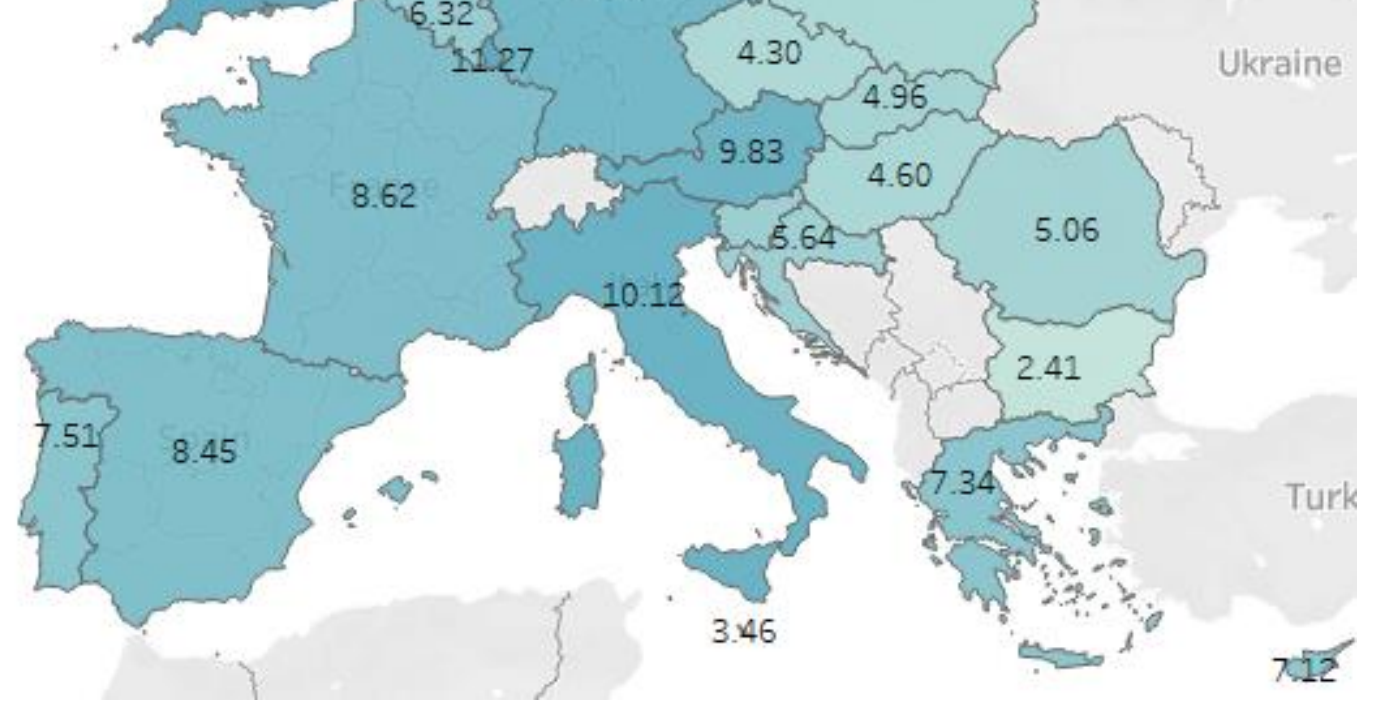

Figure A1. The map of energy productivity in the EU-28, per county, 2018. Source: Authors' own representation (raw data source: Eurostat [53], processed in Tableau Desktop 2020.3). 


\section{Greenhouse gas emissions (tonnes per capita)

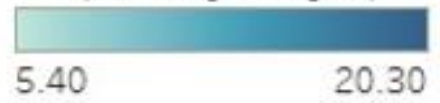

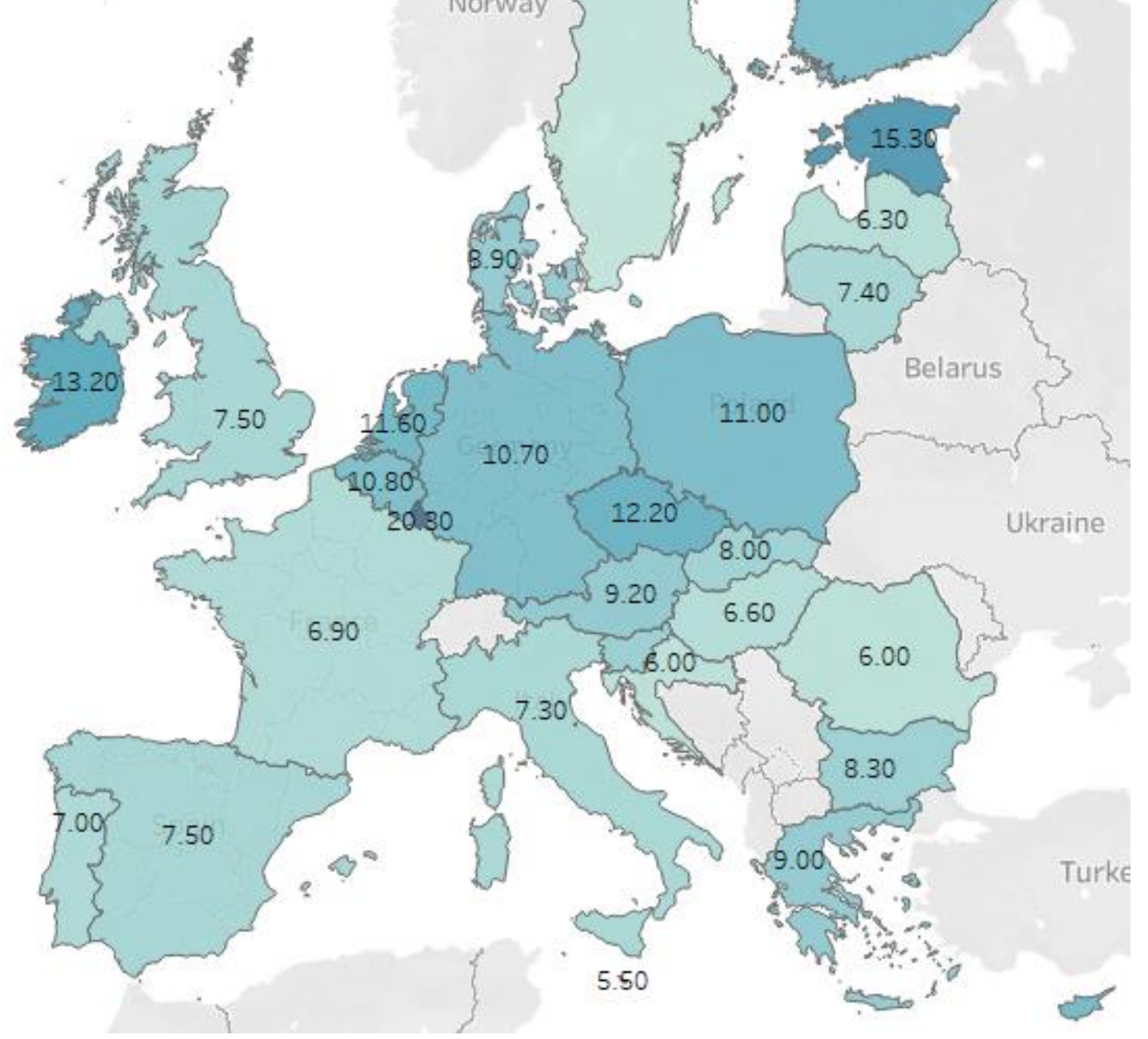

Figure A2. The map of greenhouse gas emissions in the EU-28, per county, 2018. Source: Authors' own representation (raw data source: Eurostat [53], processed in Tableau Desktop 2020.3). 

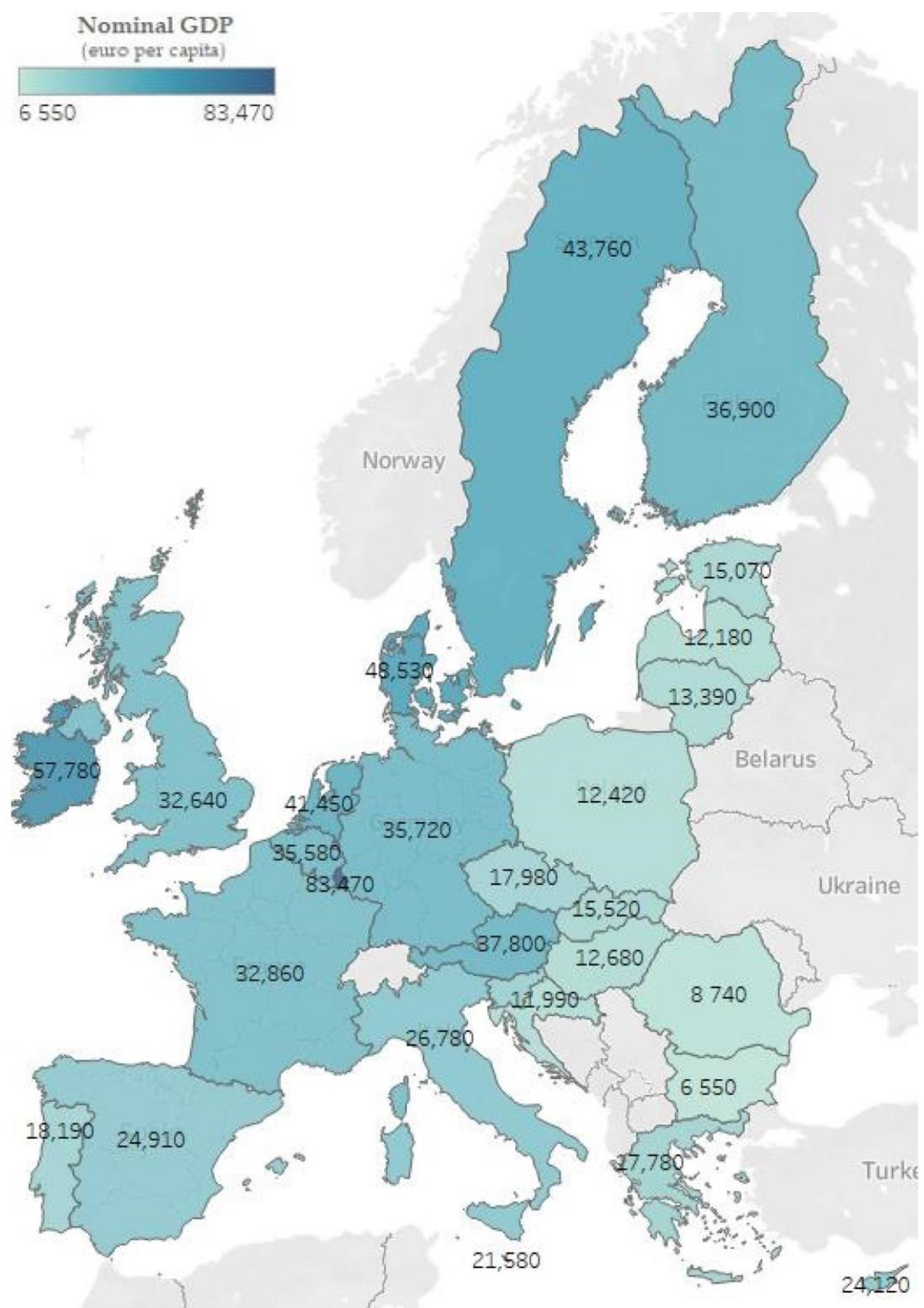

Figure A3. The map of nominal GDP in the EU-28, per county, 2018. Source: Authors' own representation (raw data source: Eurostat [53], processed in Tableau Desktop 2020.3). 


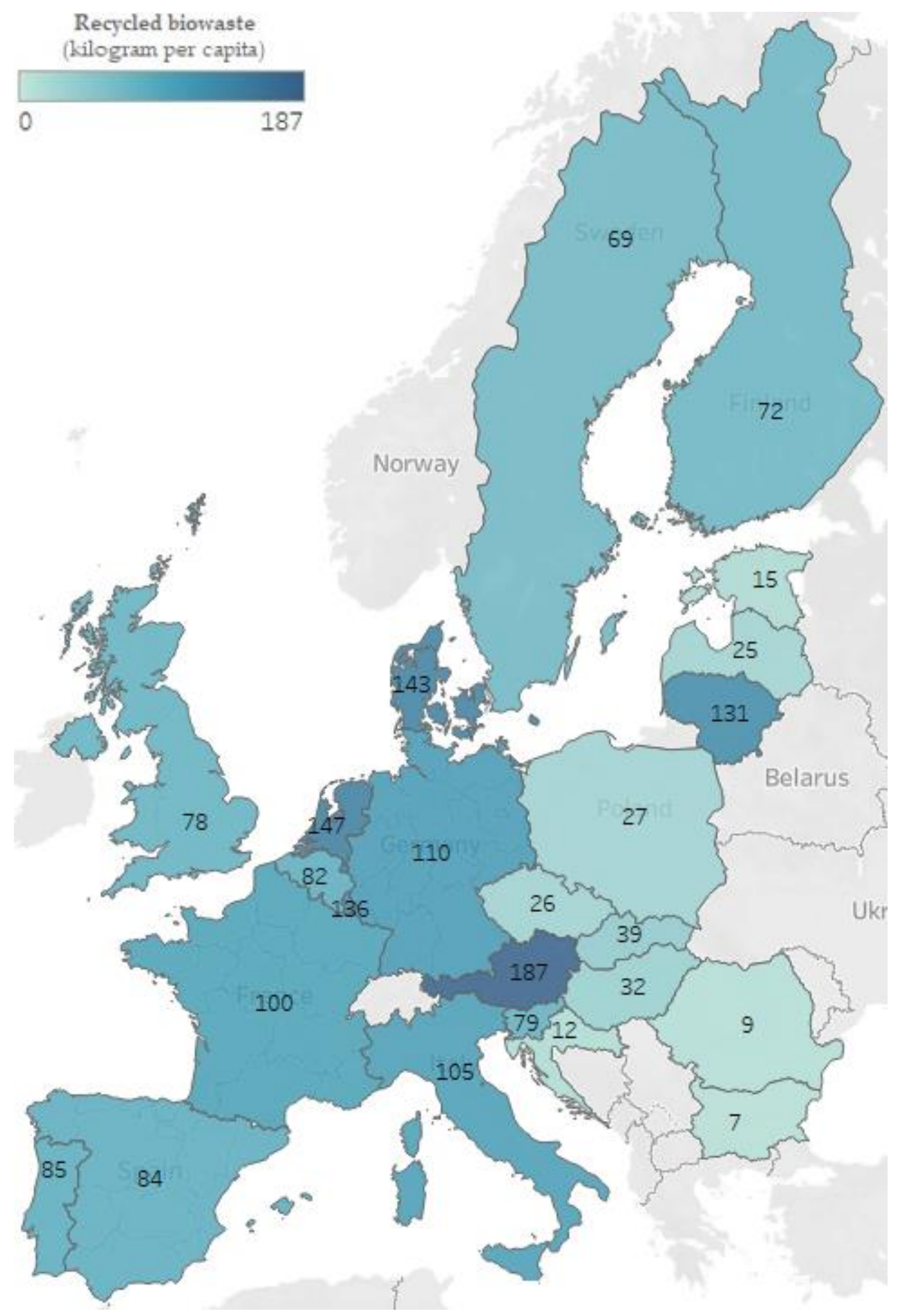

Figure A4. The map of the recycled biowaste in 2018 in the EU-28, per county, with the exception of Ireland, Greece and Cyprus, due to data unavailability. Source: Authors' own representation (raw data source: Eurostat [53], processed in Tableau Desktop 2020.3).

\section{References}

1. United Nations. Report of the World Commission on Environment and Development: Our Common Future; United Nations: New York, NY, USA, 1987.

2. United Nations. Transforming our World: The 2030 Agenda for Sustainable Development A/RES/70/1; United Nations: New York, NY, USA, 2015. 
3. Barbier, E.B.; Burgess, J.C. The sustainable development goals and the systems approach to sustainability. Econ. Open-Access Open-Assess. E-J. 2017, 11, 1-23. [CrossRef]

4. Fonseca, L.; Carvalho, F. The Reporting of SDGs by Quality, Environmental, and Occupational Health and Safety-Certified Organizations. Sustainability 2019, 11, 5797. [CrossRef]

5. Van Noordwijk, M.; Duguma, L.A.; Dewi, S.; Leimona, B.; Catacutan, D.C.; Lusiana, B.; Öborn, I.; Hairiah, K.; Minang, P.A. SDG synergy between agriculture and forestry in the food, energy, water and income nexus: Reinventing agroforestry? Curr. Opin. Environ. Sustain. 2018, 34, 33-42. [CrossRef]

6. Hornik, J.; Cherian, J.; Madansky, M.; Narayana, C. Determinants of recycling behavior: A synthesis of research results. J. Socio-Econ. 1995, 24, 105-128. [CrossRef]

7. Arias, C.; Trujillo, C.A. Perceived Consumer Effectiveness as A Trigger of Behavioral Spillover Effects: A path towards Recycling. Sustainability 2020, 12, 4348. [CrossRef]

8. Popescu, M.-F. Is Circular Economy Going to Reduce Waste and Create Jobs in the European Union? In Proceedings of the 38th International Scientific Conference on Economic and Social Development, Rabat, Morocco, 21-22 March 2019; pp. 398-406.

9. Gracia, A.; Gómez, M.I. Food Sustainability and Waste Reduction in Spain: Consumer Preferences for Local, Suboptimal, And/Or Unwashed Fresh Food Products. Sustainability 2020, 12, 4148. [CrossRef]

10. Nicholls, E.; Ely, A.; Birkin, L.; Basu, P.; Goulson, D. The contribution of small-scale food production in urban areas to the sustainable development goals: A review and case study. Sustain. Sci. 2020. [CrossRef]

11. FAO. The State of Food and Agriculture 2019: Moving Forward on Food Loss and Waste Reduction; FAO: Rome, Italy, 2019.

12. Zhang, Y.; Chabay, I. How “Green Knowledge” Influences Sustainability through Behavior Change: Theory and Policy Implications. Sustainability 2020, 12, 6448. [CrossRef]

13. Ladaru, R.; Marin, F. The synergy between Tulcea county development model proposed by the World Bank and consumption behavior of territorial administrative units | International Business Information Management Association (IBIMA). In Proceedings of the Sustainable Economic Growth, Education Excellence, and Innovation Management through Vision 2020, Vienna, Austria, 3-4 May 2017; pp. 394-404.

14. Cockerill, K.; Glynn, P.; Chabay, I.; Farooque, M.; Hämäläinen, R.P.; Miyamoto, B.; McKay, P. Records of engagement and decision making for environmental and socio-ecological challenges. EURO J. Decis. Process. 2019, 7, 243-265. [CrossRef]

15. Lăzăroiu, G.; Ionescu, L.; Uță, C.; Hurloiu, I.; Andronie, M.; Dijmărescu, I. Environmentally Responsible Behavior and Sustainability Policy Adoption in Green Public Procurement. Sustainability 2020, 12, 2110. [CrossRef]

16. Lăzăroiu, G.; Popescu, G.H.; Nica, E. The role of electronic word-of-mouth in influencing consumer repurchase intention in social commerce. SHS Web Conf. 2020, 74, 03003. [CrossRef]

17. Kliestik, T.; Valaskova, K.; Nica, E.; Kovacova, M.; Lazaroiu, G. Advanced methods of earnings management: Monotonic trends and change-points under spotlight in the Visegrad countries. Oeconomia Copernic. 2020, 11, 371-400. [CrossRef]

18. Trentmann, F. Beyond Consumerism: New Historical Perspectives on Consumption. J. Contemp. Hist. 2004, 39, 373-401. [CrossRef]

19. Geiger, S.M.; Fischer, D.; Schrader, U. Measuring What Matters in Sustainable Consumption: An Integrative Framework for the Selection of Relevant Behaviors. Sustain. Dev. 2018, 26, 18-33. [CrossRef]

20. Mont, O.; Neuvonen, A.; Lähteenoja, S. Sustainable lifestyles 2050: Stakeholder visions, emerging practices and future research. J. Clean. Prod. 2014, 63, 24-32. [CrossRef]

21. Sesini, G.; Castiglioni, C.; Lozza, E. New Trends and Patterns in Sustainable Consumption: A Systematic Review and Research Agenda. Sustainability 2020, 12, 5935. [CrossRef]

22. Andrei, J.V.; Patrascu, A.; Drăgoi, M.C.; Gogonea, R.-M.; Zaharia, R.S. Using Total Water Footprint of National Consumption as Sustainable Development Indicator-A Critical Review. Econ. Agric. 2018, 65, 1427-1447. [CrossRef]

23. Lin, S.-J.; Beidari, M.; Lewis, C. Energy Consumption Trends and Decoupling Effects between Carbon Dioxide and Gross Domestic Product in South Africa. Aerosol Air Qual. Res. 2015, 15, 2676-2687. [CrossRef]

24. Popescu, G.H.; Andrei, J.V.; Nica, E.; Mieilă, M.; Panait, M. Analysis on the impact of investments, energy use and domestic material consumption in changing the Romanian economic paradigm. Technol. Econ. Dev. Econ. 2019, 25, 59-81. [CrossRef] 
25. European Commission. The European Green Deal; European Commission: Brussels, Belgium, 2019.

26. Kaza, S.; Yao, L.; Bhada-Tata, P.; Van Woerden, F. What a Waste 2.0: A Global Snapshot of Solid Waste Management to 2050; The World Bank: Washington, DC, USA, 2018.

27. OECD. Global Material Resources Outlook to 2060: Economic Drivers and Environmental Consequences; OECD Publishing: Paris, France, 2019.

28. European Commission. A New Circular Economy Action Plan for a Cleaner and More Competitive Europe; COM/2020/98 Final; European Commission: Brussels, Belgium, 2020.

29. European Commission. Stepping up Europe's 2030 Climate Ambition Investing in a Climate-Neutral Future for the Benefit of Our People; European Commission: Brussels, Belgium, 2020.

30. Li, J.; Zhang, X.; Ali, S.; Khan, Z. Eco-innovation and energy productivity: New determinants of renewable energy consumption. J. Environ. Manag. 2020, 271, 111028. [CrossRef]

31. Gilg, A.; Barr, S.; Ford, N. Green consumption or sustainable lifestyles? Identifying the sustainable consumer. Futures 2005, 37, 481-504. [CrossRef]

32. Trudel, R. Sustainable consumer behavior. Consum. Psychol. Rev. 2019, 2, 85-96. [CrossRef]

33. Trudel, R.; Argo, J.J. The effect of product size and form distortion on consumer recycling behavior. J. Consum. Res. 2013, 40, 632-643. [CrossRef]

34. Batrancea, L.; Rathnaswamy, M.M.; Batrancea, I.; Nichita, A.; Rus, M.-I.; Tulai, H.; Fatacean, G.; Masca, E.S.; Morar Ioan, D. Adjusted Net Savings of CEE and Baltic Nations in the Context of Sustainable Economic Growth: A Panel Data Analysis. J. Risk Financ. Manag. 2020, 13, 234. [CrossRef]

35. Ioan, B.; Malar Kumaran, R.; Larissa, B.; Anca, N.; Lucian, G.; Gheorghe, F.; Horia, T.; Ioan, B.; Mircea-Iosif, R. A Panel Data Analysis on Sustainable Economic Growth in India, Brazil, and Romania. J. Risk Financ. Manag. 2020, 13, 170. [CrossRef]

36. Schumpeter, J. The Common Sense of Econometrics. Econometrica 1933, 1, 5-12. [CrossRef]

37. Skeels, C.L. Introduction to the Theory of Econometrics. Econ. Rec. 2018, 94, 209-211. [CrossRef]

38. Sahin, E.S.; Bayram, I.S.; Koc, M. Demand side management opportunities, framework, and implications for sustainable development in resource-rich countries: Case study Qatar. J. Clean. Prod. 2019, 241, 118332. [CrossRef]

39. Khan, S.A.R.; Zhang, Y.; Kumar, A.; Zavadskas, E.; Streimikiene, D. Measuring the impact of renewable energy, public health expenditure, logistics, and environmental performance on sustainable economic growth. Sustain. Dev. 2020, 28, 833-843. [CrossRef]

40. Frone, D.F.; Frone, S. Issues and Trends of Progress towards Sustainable Development Goals in Romania. Sci. Pap. Manag. Econ. Eng. Agric. Rural Dev. 2020, 20, 237-245.

41. Fader, M.; Cranmer, C.; Lawford, R.; Engel-Cox, J. Toward an Understanding of Synergies and Trade-Offs Between Water, Energy, and Food SDG Targets. Front. Environ. Sci. 2018, 6. [CrossRef]

42. Pham, T.P.T.; Kaushik, R.; Parshetti, G.K.; Mahmood, R.; Balasubramanian, R. Food waste-to-energy conversion technologies: Current status and future directions. Waste Manag. 2015, 38, 399-408. [CrossRef] [PubMed]

43. Lemaire, A.; Limbourg, S. How can food loss and waste management achieve sustainable development goals? J. Clean. Prod. 2019, 234, 1221-1234. [CrossRef]

44. Gava, O.; Bartolini, F.; Venturi, F.; Brunori, G.; Pardossi, A. Improving Policy Evidence Base for Agricultural Sustainability and Food Security: A Content Analysis of Life Cycle Assessment Research. Sustainability 2020, 12, 1033. [CrossRef]

45. Fleetwood, J. Social Justice, Food Loss, and the Sustainable Development Goals in the Era of COVID-19. Sustainability 2020, 12, 5027. [CrossRef]

46. Jin, X.; Li, Y.; Sun, D.; Zhang, J.; Zheng, J. Factors Controlling Urban and Rural Indirect Carbon Dioxide Emissions in Household Consumption: A Case Study in Beijing. Sustainability 2019, 11, 6563. [CrossRef]

47. Kokotovic, F.; Kurecic, P.; Cingula, D. The Greenhouse Gas Emission in the EU: VAR Analysis of the Relevant Variables. Int. J. Manag. Sci. Bus. Adm. 2015, 2, 37-46. [CrossRef]

48. Istudor, N.; Ion, R.A.; Petrescu, I.E.; Hrebenciuc, A. Agriculture and the Twofold Relationship between Food Security and Climate Change. Evidence from Romania. Amfiteatrul Econ. 2019, 21, 285-293. [CrossRef]

49. Sorger, G. Income and wealth distribution in a simple model of growth. Econ. Theory 2000, 16, $23-42$. [CrossRef] 
50. Slacalek, J. What Drives Personal Consumption? The Role of Housing and Financial Wealth; Social Science Research Network: Rochester, NY, USA, 2009.

51. Aslan, A.; Altinoz, B.; Özsolak, B. The nexus between economic growth, tourism development, energy consumption, and CO2 emissions in Mediterranean countries. Environ. Sci. Pollut. Res. 2020. [CrossRef]

52. Van Zanten, J.A.; van Tulder, R. Towards nexus-based governance: Defining interactions between economic activities and Sustainable Development Goals (SDGs). Int. J. Sustain. Dev. World Ecol. 2020, 1-17. [CrossRef]

53. Eurostat. Eurostat Databases Online; Eurostat: Luxembourg, 2020.

54. Losada, R.G. The social rights of citizens of the European Union and the United Kingdom. Free circulation of workers and Social Security after the Brexit. Rev. Gen. Derecho Trab. Segur. Soc. 2019, 52, 92-135.

55. Haining, R.P. Data Problems in Spatial Econometric Modeling. In New Directions in Spatial Econometrics; Anselin, L., Florax, R.J.G.M., Eds.; Advances in Spatial Science; Springer: Berlin/Heidelberg, Germany, 1995; pp. 156-171. ISBN 978-3-642-79877-1.

56. Eurostat. Energy Productivity (SDG_07_30) Indicator Profile; Eurostat: Luxembourg, 2020.

57. Sala, S.; Castellani, V. The consumer footprint: Monitoring sustainable development goal 12 with process-based life cycle assessment. J. Clean. Prod. 2019, 240, 118050. [CrossRef] [PubMed]

58. Acheampong, M.; Ertem, F.C.; Kappler, B.; Neubauer, P. In pursuit of Sustainable Development Goal (SDG) number 7: Will biofuels be reliable? Renew. Sustain. Energy Rev. 2017, 75, 927-937. [CrossRef]

59. Büyüközkan, G.; Karabulut, Y.; Mukul, E. A novel renewable energy selection model for United Nations' sustainable development goals. Energy 2018, 165, 290-302. [CrossRef]

60. Franco, I.B.; Power, C.; Whereat, J. SDG 7 Affordable and Clean Energy. In Actioning the Global Goals for Local Impact: Towards Sustainability Science, Policy, Education and Practice; Science for Sustainable Societies; Franco, I.B., Chatterji, T., Derbyshire, E., Tracey, J., Eds.; Springer: Singapore, 2020; pp. 105-116. ISBN 978-981-329-927-6.

61. Radulescu, M.; Fedajev, A.; Sinisi, C.I.; Popescu, C.; Iacob, S.E. Europe 2020 Implementation as Driver of Economic Performance and Competitiveness. Panel Analysis of CEE Countries. Sustainability 2018, 10, 566. [CrossRef]

62. Popescu, M.-F. The Economics and Finance of Energy Security. Procedia Econ. Financ. 2015, 27, 467-473. [CrossRef]

63. Cepoi, C.-O. Asymmetric dependence between stock market returns and news during COVID-19 financial turmoil. Financ. Res. Lett. 2020, 36, 101658. [CrossRef]

64. Eurostat. Recycling of Biowaste (CEI_WM030) Indicator Profile; Eurostat: Luxembourg, 2020.

65. European Commission. Closing the Loop-An EU Action Plan for the Circular Economy COM/2015/0614 Final-European Environment Agency; European Commission: Brussels, Belgium, 2015.

66. Moraga, G.; Huysveld, S.; Mathieux, F.; Blengini, G.A.; Alaerts, L.; Van Acker, K.; de Meester, S.; Dewulf, J. Circular economy indicators: What do they measure? Resour. Conserv. Recycl. 2019, 146, 452-461. [CrossRef]

67. Banacu, C.S.; Busu, M.; Ignat, R.; Trica, C.L. Entrepreneurial Innovation Impact on Recycling Municipal Waste. A Panel Data Analysis at the EU Level. Sustainability 2019, 11, 5125. [CrossRef]

68. Razza, F.; D'Avino, L.; L'Abate, G.; Lazzeri, L. The role of compost in bio-waste management and circular economy. In Designing Sustainable Technologies, Products and Policies; Springer: Cham, Switzerland, 2018; pp. 133-143.

69. Morone, P.; Koutinas, A.; Gathergood, N.; Arshadi, M.; Matharu, A. Food waste: Challenges and opportunities for enhancing the emerging bio-economy. J. Clean. Prod. 2019, 221, 10-16. [CrossRef]

70. Di Maria, F.; Sisani, F.; Contini, S. Are EU waste-to-energy technologies effective for exploiting the energy in bio-waste? Appl. Energy 2018, 230, 1557-1572. [CrossRef]

71. Eurostat. Greenhouse Gas Emission (SDG_13_10) Indicator Profile; Eurostat: Luxembourg, 2020.

72. Kokotović, F.; Kurečić, P.; Mjeda, T. Accomplishing the Sustainable Development Goal 13—Climate Action and the Role of the European Union. Interdiscip. Descr. Complex Syst. INDECS 2019, 17, 132-145. [CrossRef]

73. European Commission. Europe 2020. A European Strategy for Smart, Sustainable and Inclusive Growth; European Commission: Brussels, Belgium, 2010.

74. European Commission. A European Strategy for Low-Emission Mobility; European Commission: Brussels, Belgium, 2016.

75. European Commission. Accelerating Clean Energy Innovation; European Commission: Brussels, Belgium, 2016. 
76. Vasylieva, T.; Lyulyov, O.; Bilan, Y.; Streimikiene, D. Sustainable Economic Development and Greenhouse Gas Emissions: The Dynamic Impact of Renewable Energy Consumption, GDP, and Corruption. Energies 2019, 12, 3289. [CrossRef]

77. Lyeonov, S.; Pimonenko, T.; Bilan, Y.; Štreimikienè, D.; Mentel, G. Assessment of Green Investments' Impact on Sustainable Development: Linking Gross Domestic Product Per Capita, Greenhouse Gas Emissions and Renewable Energy. Energies 2019, 12, 3891. [CrossRef]

78. Lu, W.-C. Greenhouse Gas Emissions, Energy Consumption and Economic Growth: A Panel Cointegration Analysis for 16 Asian Countries. Int. J. Environ. Res. Public Health 2017, 14, 1436. [CrossRef] [PubMed]

79. McCullough, B.D. Review of Econometric Software Reliability: EViews, LIMDEP, SHAZAM and TSP. J. Appl. Econ. 1999, 14, 191-202. [CrossRef]

80. Doane, D.P.; Seward, L.E. Measuring Skewness: A Forgotten Statistic? J. Stat. Educ. 2011, 19. [CrossRef]

81. Westfall, P.H. Kurtosis as Peakedness, 1905-2014. R.I.P. Am. Stat. 2014, 68, 191-195. [CrossRef]

82. Jarque, C.M. Jarque-Bera Test. In International Encyclopedia of Statistical Science; Lovric, M., Ed.; Springer: Berlin/Heidelberg, Germany, 2011; pp. 701-702. ISBN 978-3-642-04898-2.

83. Startz, R. EViews Illustrated; University of California: Santa Barbara, CA, USA, 2019.

84. Miles, J. R Squared, Adjusted R Squared. In Wiley StatsRef: Statistics Reference Online; American Cancer Society: Atlanta, GA, USA, 2014; ISBN 978-1-118-44511-2.

85. Ali, M.M. Durbin-Watson and Generalized Durbin-Watson Tests for Autocorrelations and Randomness. J. Bus. Econ. Stat. 1987, 5, 195-203. [CrossRef]

86. Chiripuci, B.; Todirica, I.; Toderasc, A. The Impact of Globalization Phenomena on Food Safety. In Proceedings of the 1st International Conference on Economics and Social Sciences, Bucharest University of Economic Studies, Bucharest, Romania, 16-17 April 2018; Volume 1, pp. 21-27.

87. Lakatos, E.S.; Cioca, L.-I.; Dan, V.; Ciomos, A.O.; Crisan, O.A.; Barsan, G. Studies and Investigation about the Attitude towards Sustainable Production, Consumption and Waste Generation in Line with Circular Economy in Romania. Sustainability 2018, 10, 865. [CrossRef]

88. Piligrimienė, Ž.; Žukauskaitè, A.; Korzilius, H.; Banytė, J.; Dovalienė, A. Internal and External Determinants of Consumer Engagement in Sustainable Consumption. Sustainability 2020, 12, 1349. [CrossRef]

89. Santiago, M.R.; Bezerro, E.B.E. Consumer Relations in Post-Modernity; Collaborative Consumption as a Sustainability Instrument. Direito Cid. 2017, 9, 463-482.

Publisher's Note: MDPI stays neutral with regard to jurisdictional claims in published maps and institutional affiliations.

(C) 2020 by the authors. Licensee MDPI, Basel, Switzerland. This article is an open access article distributed under the terms and conditions of the Creative Commons Attribution (CC BY) license (http://creativecommons.org/licenses/by/4.0/). 